GEOLOGY AND SEISMIC STRATIGRAPHY OF THE ANTARCTIC MARGIN, PART 2

ANTARCTIC RESEARCH SERIES, VOLUME 71, PAGES 95-108

\title{
SEISMIC EXPRESSION OF GLACIALLY DEPOSITED SEQUENCES IN THE BELLINGSHAUSEN AND AMUNDSEN SEAS, WEST ANTARCTICA
}

\author{
Frank O. Nitsche ${ }^{1}$, Karsten Gohl ${ }^{1,3}$, Kris Vanneste $^{2,4}$ Heinz Miller ${ }^{1}$
}

\begin{abstract}
As part of a reconnaissance survey of the West Antarctic continental margin, multichannel seismic data were acquired on the continental shelf, slope and rise of the Bellingshausen and Amundsen Seas during the cruise ANT-XI/3 of RV Polarstern in early 1994. The seismic data provide an overview of the large scale stratigraphic architecture of the margin between $73^{\circ} \mathrm{W}$ and $122 \mathrm{~W}$. Four lines extend across the outer shelf and slope to the continental rise, showing seismic sequences interpreted as having been produced by glacial and glacial-marine processes. Predominantly prograding sequences on the outer shelf and upper slope suggest that a grounded ice sheet advanced toward and across the shelf break several times during the glacial evolution of this region of Antarctica. Comparison of the profiles reveals that significant differences, but also striking similarities exist in the stratal patterns along the margin. Similar phases of progradation and aggradation observed on all of the profiles indicate a consistent long-term glacial development along the margin of the Amundsen and Bellingshausen Seas.
\end{abstract}

\section{INTRODUCTION}

The identification and stratal geometry of glacially deposited sediments on the Antarctic continental shelves provide significant clues for the reconstruction of the glacial history of West Antarctica and, more generally, of the climatic evolution of the southern hemisphere. Drilling results from several DSDP and ODP sites indicate that grounded ice first advanced across the continental shelf at the beginning of the Oligocene in East Antarctica and during the Miocene in West Antarctica [Ehrmann and Mackensen, 1992; Anderson and Bartek, 1992]. This Cenozoic glaciation caused a major change in the characteristics of depositional sequences on the Antarctic continental margins that can be seen on seismic reflection profiles. The repeated phases of glacial and interglacial

\footnotetext{
'Alfred-Wegener-Institute for Polar and Marine Research, Bremerhaven, Germany

${ }^{2}$ Renard Centre of Marine Geology, University of Gent, Gent, Belgium

${ }^{3}$ now at: School of Earth Sciences, Macquarie University, Sydney, Australia

${ }^{4}$ now at: Royal Observatory of Belgium, Brussels, Belgium
}

periods result in a distinct form of prograding sequence [Cooper et al., 1991] of different geometry from those found at low-latitude margins [Larter and Cunningham, 1993]. Previously, these features have been studied intensively in the Weddell Sea [Kuvaas and Kristofferson, 1991], Ross Sea [Anderson and Bartek, 1992], Prydz Bay [Cooper et al., 1991] and on the Antarctic Peninsula Pacific margin [Larter and Barker, 1989, 1991a].

Cooper et al. [1991] summarized and compared results from the different regions. They distinguished two major reflection geometries seen in all studied areas: Type IA and Type IIA. Type IA sequences account for most progradation of the Antarctic continental shelves and show a complex sigmoidal or tangential oblique geometry. Type IIA sequences, which underlie type IA, are characterized by gently dipping reflections, and are thought to be generated prior to the onset of the major glacial advance of a grounded ice sheet. Sedimentation processes at that time might have been similar to those at low-latitude margins, although some early glacial-marine or glacial processes might have occurred in inner shelf or coastal regions. During times of ice sheet expansion and glacial maxima the sediment supply was increased by 
glacial erosion, and deposition took place in front of the grounding line. When the ice sheet reached the shelf break, it resulted in progradation of the shelf edge while the topset section of the sequences underlying the ice sheet might have been eroded. This happened many times on the margins around Antarctica. Sometimes, thin layers of topset sediments may be present between two prograding sequences deposited during different glacial cycles. But in many cases it is also probable that the topset layer deposited between two glacial advances has been totally eroded by the later advance. Therefore, it is impossible to resolve all glacial-interglacial cycles on seismic reflection profiles.

Due to the increase in sediment supply to the slope during glacial maxima it is likely that the input to the continental rise increased as well, as rapid deposition on the upper slope would have caused slumps and debris flows, which in turn probably initiated high energy turbidity currents [Anderson et al., 1991; Larter and Cunningham, 1993]. Evidence for this can be seen in drilling results from DSDP Site 325 , located $170 \mathrm{~km}$ from the foot of the Antarctic Peninsula continental slope. Late Miocene increase in sedimentation rate at this site may be related to onset of grounded ice advances on the shelf [Tucholke and Houtz, 1976].

As along the Antarctic Peninsula margin, sedimentation in the Bellingshausen Sea is influenced by both tectonic and glacial history [Tucholke and Houtz, 1976; Larter and Barker, 1991a]. The tectonic history of the continental margin of the Antarctic Peninsula and the central and eastern Bellingshausen Sea is dominated by subduction of the Phoenix plate which stopped after the collision of the Phoenix-Antarctic ridge and the Pacific margin of the Antarctic Peninsula. This collision occurred in successive steps from the southwest to the northeast between 55Ma and4 Ma [Larter and Barker, 1991b]. Because the collision of the Phoenix-Antarctic ridge and the Antarctic Peninsula margin happened so much earlier in the central Bellingshausen Sea than at the Antarctic Peninsula, tectonic processes were probably a minor influence on sedimentation during glacial times, compared to the Peninsula region. Due to the sparse geophysical data available, the tectonic history of the western Bellingshausen Sea is unclear. In contrast to the Bellingshausen Sea and Antarctic Peninsula margin, the margin of the Amundsen Sea was divergent, formed as New Zealand rifted away from West Antarctica about 90Ma ago [Lawver et al., 1992].

The ice sheets on northern Ellsworth Land and Marie Byrd Land drained mainly into the Bellingshausen and Amundsen Seas. Only a few expeditions have collected seismic data in the shelf region and on the continental rise of the Bellingshausen and Amundsen Seas [Tucholke and Houtz, 1976; Kimura, 1982; Cunningham et al., 1994]. In addition, these studies, except for the one reported by Cunningham et al. [1994], surveyed the continental rise only in the area west of $78^{\circ} \mathrm{W}$.

During the austral summer of 1994, the Alfred Wegener Institute of Polar and Marine Research carried out a geoscientific reconnaissance survey with RV Polarstern (cruise ANT-XI/3) to investigate the shelf and slope region between $73^{\circ} \mathrm{W}$ and $122^{\circ} \mathrm{W}$ (Figure 1). The survey had two objectives. Firstly, it was intended to investigate glacial and glacial-marine deposition along the shelf edges and, secondly, it attempted to image the tectonic structure of the deeper sediments and acoustic basement in order to advance understanding of the tectonic history of these continental margins. In this paper, we concentrate on the analysis of stratal geometry patterns seen on seismic reflection profiles across the continental slope and outer shelf, and the implications for glacial history.

\section{DATA ACQUISITION}

The ANT XI/3 survey with RV Polarstern resulted in the acquisition of about $3000 \mathrm{~km}$ of multichannel seismic data in regions of the Bellingshausen and Amundsen Seas that were accessible in the period January-March 1994 (Figure 1). The data are clustered in four areas: (1) on the slope and rise off Alexander Island (lines AWI-94002 and 94003), (2) within the Ronne Entrance (lines AWI-94010 and 94020), (3) on the slope and rise of the Bellingshausen Sea south and southwest of Peter I Island (lines AWI-94030, 94040, 94041 and 94043) and (4) in the east and central Amundsen Sea (lines AWI-94042, 94050 and 94054).

(1) AWI-94002 and AWI-94003 are the easternmost lines that were recorded. These are long transects running from the outer shelf down the continental slope and onto the continental rise crossing distinctly different domains of the West Antarctic continental margin, separated by a change in margin strike direction. The continental slope crossed by line AWI-94002 is extremely steep $\left(\sim 15^{\circ}\right)$ and strikes southwest-northeast. Line AWI-94003 crosses a slope whose more gentle dip $\left(\sim 3^{\circ}\right)$ and strike (westsouthwest to east-northeast) are more typical of the Bellingshausen Sea margin.

(2) The lines AWI-94010 and AWI-94020 are the southernmost profiles so far acquired in this region. They are located in the Ronne Entrance, a broad glacially eroded valley on the inner continental shelf, extending 


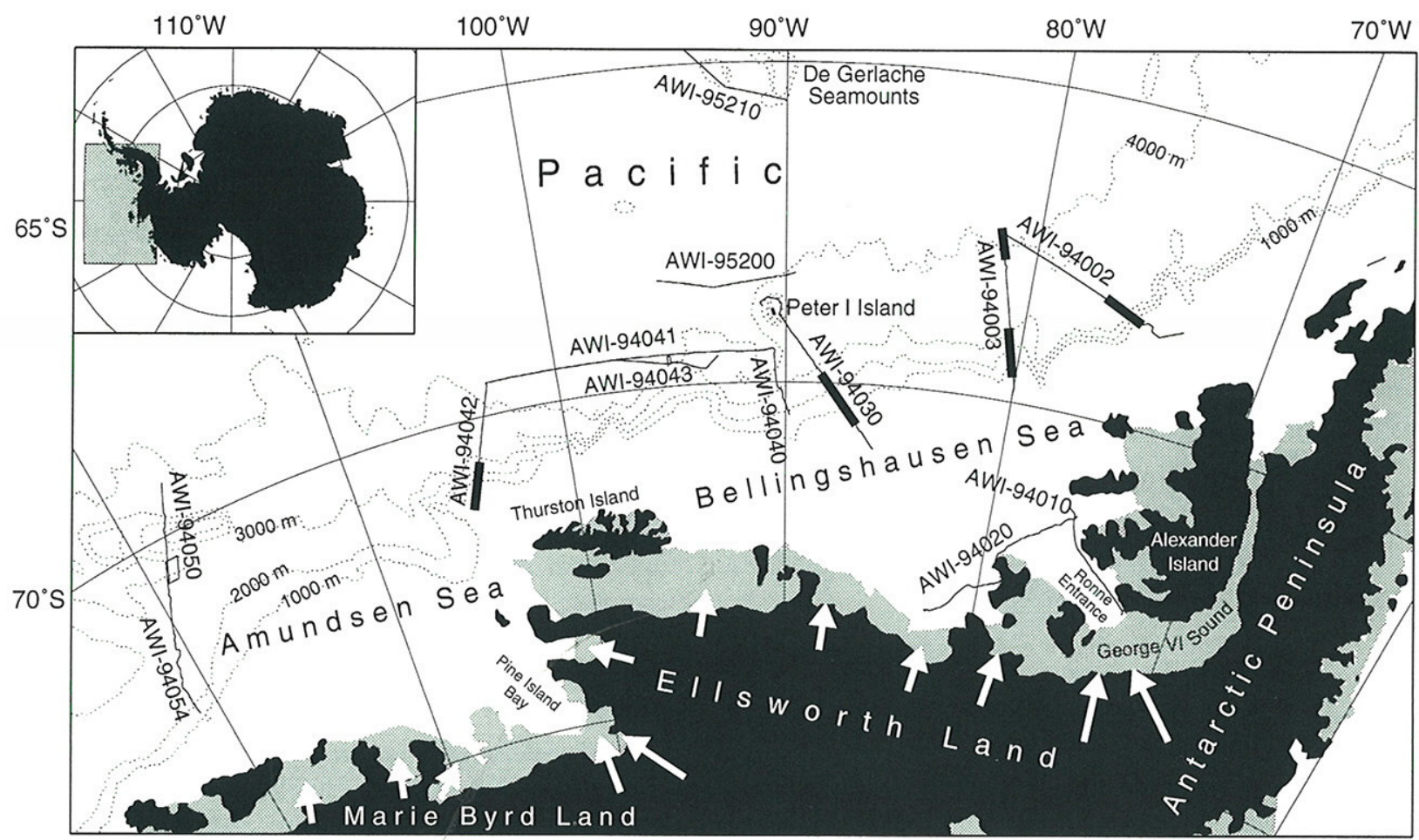

Fig. 1. Locations of multichannel seismic profiles acquired during RV Polarstern cruise ANT-XI/3 in 1994 and ANT XII/4 in 1995. The bold parts of profiles AWI-94002, AWI-94003, AWI-94030 and AWI-94042 mark sections shown in this paper. Bathymetry is approximated by $1000 \mathrm{~m}$ contours (dotted lines), showing the change of continental slope gradient along the margin from steep along the Antarctic Peninsula to more gentle in the Bellingshausen and Amundsen Sea areas. The white arrows are possible areas of high ice supply [ice flow lines of Drewry, 1983].

from George VI Sound. Line AWI-94010 was shot along the eastern rim of the Entrance, parallel to the southeastern shore of Alexander Island. Line AWI-94020 is a transverse profile across the Ronne Entrance.

(3) Five lines are located in the central and western Bellingshausen Sea. Line AWI-94030 is a complete shelfslope-rise transect, running from the outer shelf downslope towards Peter I Island, a volcanic island lying due south of the De Gerlache Seamounts and towering more than $4000 \mathrm{~m}$ above the surrounding continental rise. Line AWI-94040 is a shorter traverse slightly farther west. Line AWI-94041 is a slope-parallel line extending from just south of Peter I Island towards the west. It was shot to investigate a large anomaly in the free-air gravity field of this area [McAdoo and Marks, 1992; Gohl et al., in press a]. Line AWI-94043 represents an additional profile across this peculiar feature.

(4) The remaining lines are all located in the Amundsen Sea. Line AWI-94042 traverses the continental margin near the boundary between the Bellingshausen and
Amundsen Seas. Lines AWI-94050 and AWI-94054 form an incomplete transect in the central Amundsen Sea, in the vicinity of the Marie Byrd Seamounts. Unfortunately, heavy pack ice prevented southward continuation of the lines onto the upper slope and outer shelf.

We used several configurations of the seismic acquisition system ranging from low to intermediate resolution $(20 \mathrm{~Hz}-150 \mathrm{~Hz})$. The profiles in the east (AWI94002, AWI-94003, and AWI-94020) were shot with an array of eight airguns of 3 liters volume each $(20 \mathrm{~Hz}$ $100 \mathrm{~Hz}$ ) and a $2400 \mathrm{~m}$-long active streamer of 96 channels. Because of damage to the streamer at the end of profile AWI-94020, subsequent profiles to the west were recorded with a $600 \mathrm{~m}$-long streamer of 96 channels and the same airgun array. We used a cluster of three 4.5 liter GI guns $(30 \mathrm{~Hz}$ to $150 \mathrm{~Hz})$ for profile AWI-94030. The aim was to investigate the entire sedimentary section from the continental rise up to the shelf, but because of ice conditions only four profiles reached the shelf edge (AWI-94002, AWI-94003, AWI-94030, AWI-94042), 
while the others ended on the upper continental slope. The airguns were towed at a depth of $5 \mathrm{~m}$, while the streamer was towed at $10 \mathrm{~m}$.

Standard data processing procedures were applied to the seismic data: after demultiplexing and spherical divergence correction the data were sorted into $25 \mathrm{~m}$ spaced CDP's. Then a NMO-correction was applied and the data were normal stacked. Before displaying, the stacked sections were enhanced using AGC and a bandpass filter between $15 \mathrm{~Hz}$ and $100 \mathrm{~Hz}(150 \mathrm{~Hz}$ for AWI-94030). To suppress the sea floor multiples on the shelves a fk-velocity filter was used before stacking the data. Because of the strong multiple reflections, this has only been partly successful.

\section{STRATAL GEOMETRY OF THE SHELF, SLOPE AND RISE}

Due to the inaccessibility of the inner shelf area, seismic work during cruise ANT-XI/3 was concentrated on the outer continental shelf, slope and rise. Limited data are available, however, from the Ronne Entrance part of the inner shelf (Figure 1). These lines (AWI-94010 and 94020 , not shown here) reveal a generally overdeepened area, with depths up to $900 \mathrm{~m}$. Basement is partly exposed at the sea floor in the western part, indicated by strong reflections. Across the Ronne Entrance the data show folded sediments partly eroded at the top. These data cannot be connected to the lines at the continental margin on which this study is concentrated.

The wedge of sediments accumulated along the margin is seen on the long shelf-to-rise transects perpendicular to the shelf edge. We will briefly discuss the stratal geometry patterns on four transects, proceeding from east to west along the margin.

\subsection{Line AWI-94002, Eastern Bellingshausen Sea}

Line AWI-94002 (Figure 2a and 3) crosses a steep and narrow continental slope, which falls approximately $2550 \mathrm{~m}$ over a distance of $10 \mathrm{~km}$, resulting in a gradient of c. $15^{\circ}$. The outer shelf (Figure 3 ), where the water depth is c. $460 \mathrm{~m}$, shows three distinct units: Unit 1, a lower unit of parallel and gently $\left(<1^{\circ}\right)$ seaward-dipping strata that we interpret as topsets, of which the associated foresets are not observed; Unit 2, a middle unit of mainly progradational and, toward the top, truncated sequences with no topset section preserved, and Unit 3, an upper unit characterized by both progradation and aggradation, the latter becoming increasingly important towards the top. Unit 2 is built out above Unit 1 and thins landward. The dip of reflections inside Unit 2 steepens towards the shelf break from $4^{\circ}-5^{\circ}$ to $12^{\circ}-14^{\circ}$. The topset section of Unit 3 , up to $200 \mathrm{~ms}$ thick (two-way time) of horizontally stratified sediments on the shelf, overlies Unit 2. The tota distance of progradation for the two upper units is $14 \mathrm{~km}$. Several indications of slump and slide structures are seen on the continental slope and on the paleo-slope beyond the outer shelf.

On the continental rise (Figure $2 \mathrm{a}$ ), up to $2 \mathrm{~s}$ of sediments are accumulated above a reflection interpreted as the top of oceanic volcanic layer 2. At the upper continental rise, in the upper few hundred milliseconds, there is an interval of sediment accumulation, exhibiting a strikingly irregular surface morphology produced by several channel- or gully-like erosional structures (Figure 4). The deepest channel lies at the foot of the continental slope and cuts about $200 \mathrm{~m}$ into the sea floor, separating this mound from the continental slope.

\subsection{Line AWI-94003, Central Bellingshausen Sea}

The geometry on line AWI-94003 (Figures 2b and 5), located at about $80^{\circ} \mathrm{W}$, is quite different from that on the previous profile. The slope is wider and has a much more gentle gradient of $2^{\circ}$ to $3^{\circ}$. This makes it easier to trace certain reflections from the outer shelf down the slope. Below the outer shelf, c. $525 \mathrm{~m}$ deep, a similar three-unit succession of geometries is observed (Figure 5) as on line AWI-94002. The lower unit (Unit 1) consists of parallel and gently seaward dipping strata, showing at least $800 \mathrm{~ms}$ of topsets. Above this lies a mainly progradational unit (Unit 2) whose upper boundary on the shelf is an erosional surface. The upper unit (Unit 3) shows both modest progradation and upward increasing aggradation, resulting in a cover of horizontally stratified sediments over the shelf of c. $400 \mathrm{~ms}$. This is about twice the thickness of the corresponding unit on line AWI-94002. Total progradation of Unit 2 and Unit 3 is about $18 \mathrm{~km}$.

On the continental slope and rise (Figure 2b) a reflection we interpret again as the top of oceanic volcanic layer 2, is buried beneath 2.0 s to $2.5 \mathrm{~s}$ of sediments. Most prominent within this sedimentary section is an irregular, wavy-hummocky surface under which reflections are truncated upslope. Overlying sediments form a wedge of prograding strata up to $1.8 \mathrm{~s}$ thick that downlap seaward onto the erosional surface. This surface seems to correspond to the reflection which marks the boundary between Unit 1 and Unit 2. The wedge thins dramatically to c. $200 \mathrm{~ms}$ on the lower slope.

On the continental rise the upper sediments form a c. $400 \mathrm{~ms}$ thick, transparent mound, which is locally associated with sediment waves at the sea floor (Figure 6). 

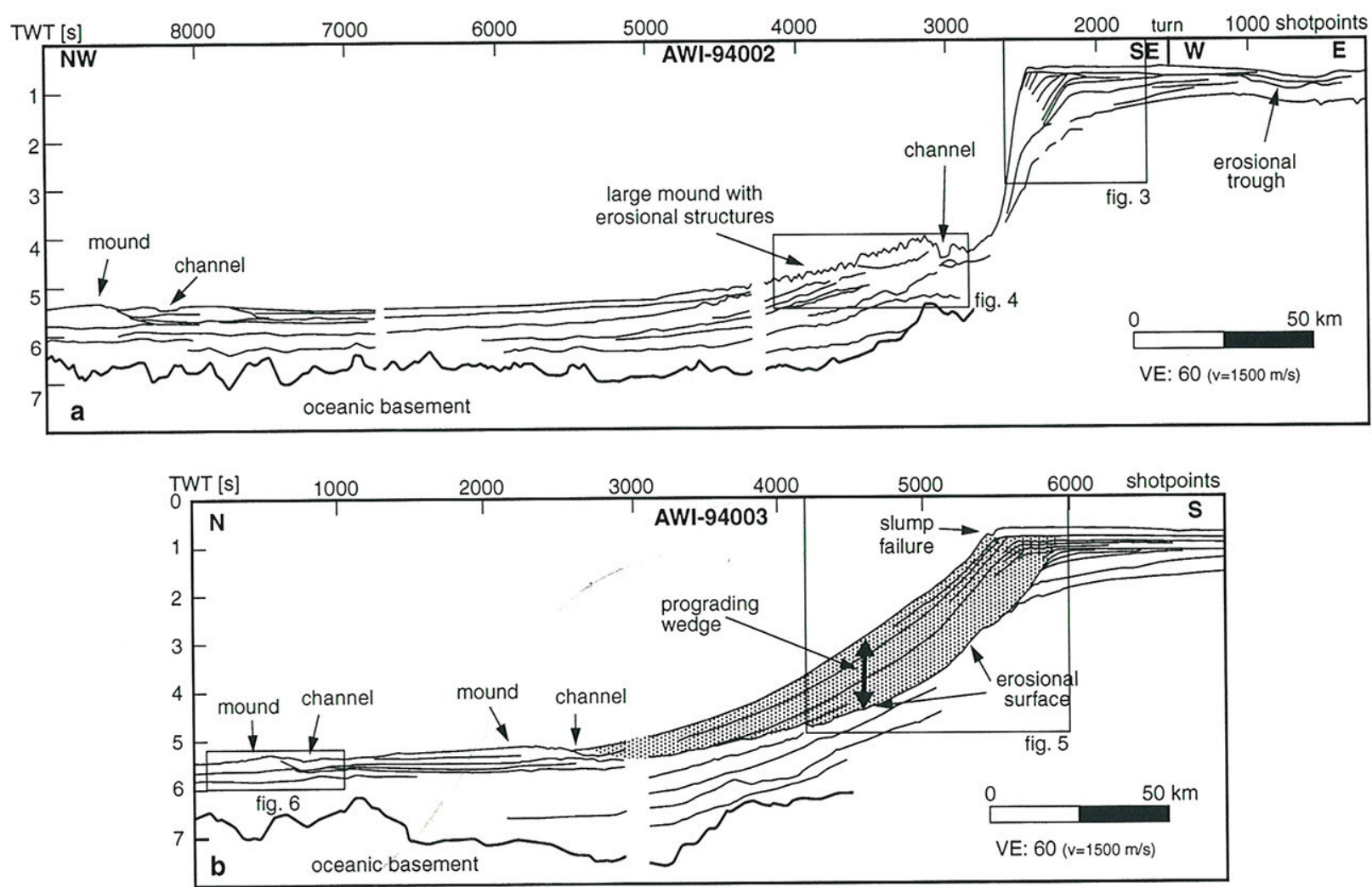

Fig. 2. Line drawings of profiles (a) AWI-94002 and (b) AWI-94003. Line AWI-94002 runs parallel to the shelf edge until shotpoint 1800 , where it turns perpendicular to the shelf. Both drawings are displayed at the same scale. Note the contrasting slope gradients. The lines are connected at their northern ends (Figure 1). Hence the mound features at that end of both profiles belong to the same structure. Enlarged sections shown in Figures 3, 4, 5 and 6 are indicated by the boxes.

The mound is seen also on the adjacent extremity of line AWI-94002 (Figure 2a), where it shows an asymmetric shape with a broad southeastern and a narrower northwestern shoulder, separated by a more than $50 \mathrm{~m}$ deep channel-like depression. It also appears to be perched against the eroded flank of an older but similarlooking transparent mass about $500 \mathrm{~m}$ thick. The upper sediment mound might be similar to a chain of large mounds identified by Rebesco et al. [1994, 1996] along the continental rise of the Antarctic Peninsula Pacific margin. The mounds are hemipelagic sediment drifts, inferred to have been deposited by a combination of channelised turbidity currents traversing the continental rise, and along-slope bottom currents [McGinnis and Hayes, 1994; Rebesco et al., 1994, 1996].

\subsection{Line AWI-94030, Western Bellingshausen Sea}

The continental slope on line AWI-94030 (Figure 7) dips more gently $\left(1^{\circ}\right.$ to $\left.2^{\circ}\right)$ and is much broader than on any of the other transects. The correlation from the outer shelf to the slope is therefore easiest to establish on this profile. Also remarkable is the shelf edge depth of about $700 \mathrm{~m}$. The outer shelf sequence geometries change again from a lower unit of thick parallel, gently dipping sequences (Unit 1), through a middle unit of mainly prograding sequences (Unit 2) into an upper unit of progradational/aggradational sequences (Unit 3). The topset deposits of the upper unit have a thickness of only $150 \mathrm{~ms}$. The same stratal patterns are noted on a nearby seismic profile recorded by the British Antarctic Survey [Cunningham et al., 1994], although some differences in the detailed structure exist.

The continental slope is underlain by a prograding wedge, delimited at its base by a horizon with characteristics very much like the base-wedge reflector observed on line AWI-94003. This reflector has a wavy-hummocky topography, is erosional up-slope and defines a downlap surface for overlying strata. Its correlation with the stratigraphy on the outer shelf is hampered by strong sea- 


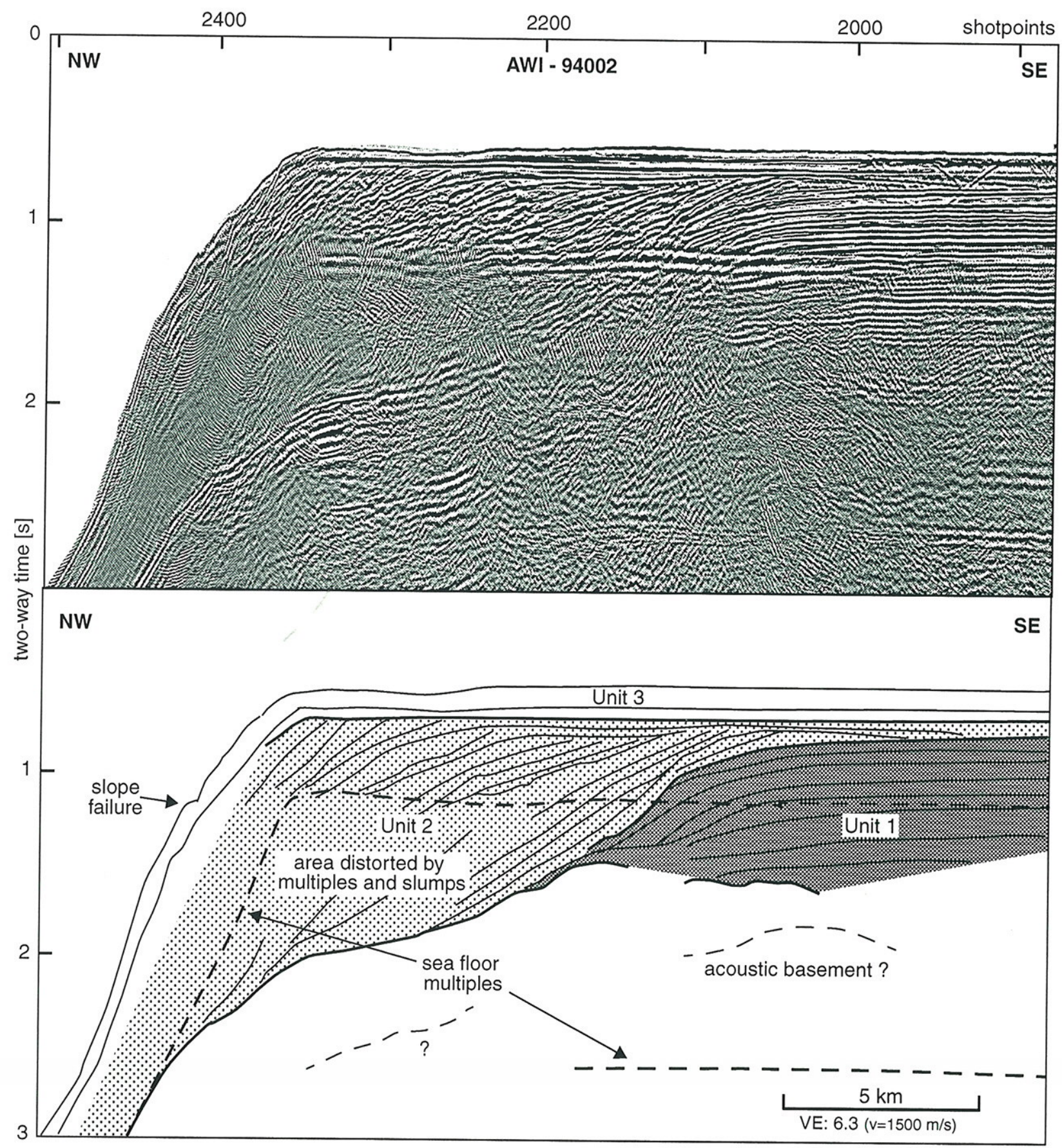

Fig. 3. A stacked seismic section of part of the outer shelf of profile AWI-94002 with interpretive line drawing. Three major units are distinguished. Unit 1 has a small dip and onlaps the underlying acoustic basement, Unit 2 is a mainly progradational sequence and Unit 3 shows aggradation as well as progradation.

floor multiples, but it appears to correlate approximately with the transition between the lower Unit 1 and the middle, purely progradational units. The limited thickness of the prograding wedge (1.0s compared with $1.8 \mathrm{~s}$ on the adjacent lines) does not necessarily indicate a lower sediment supply, but may be related to the broader and gentler slope. The total distance of progradation $(32 \mathrm{~km})$ is the greatest observed on any part of the margin. The 


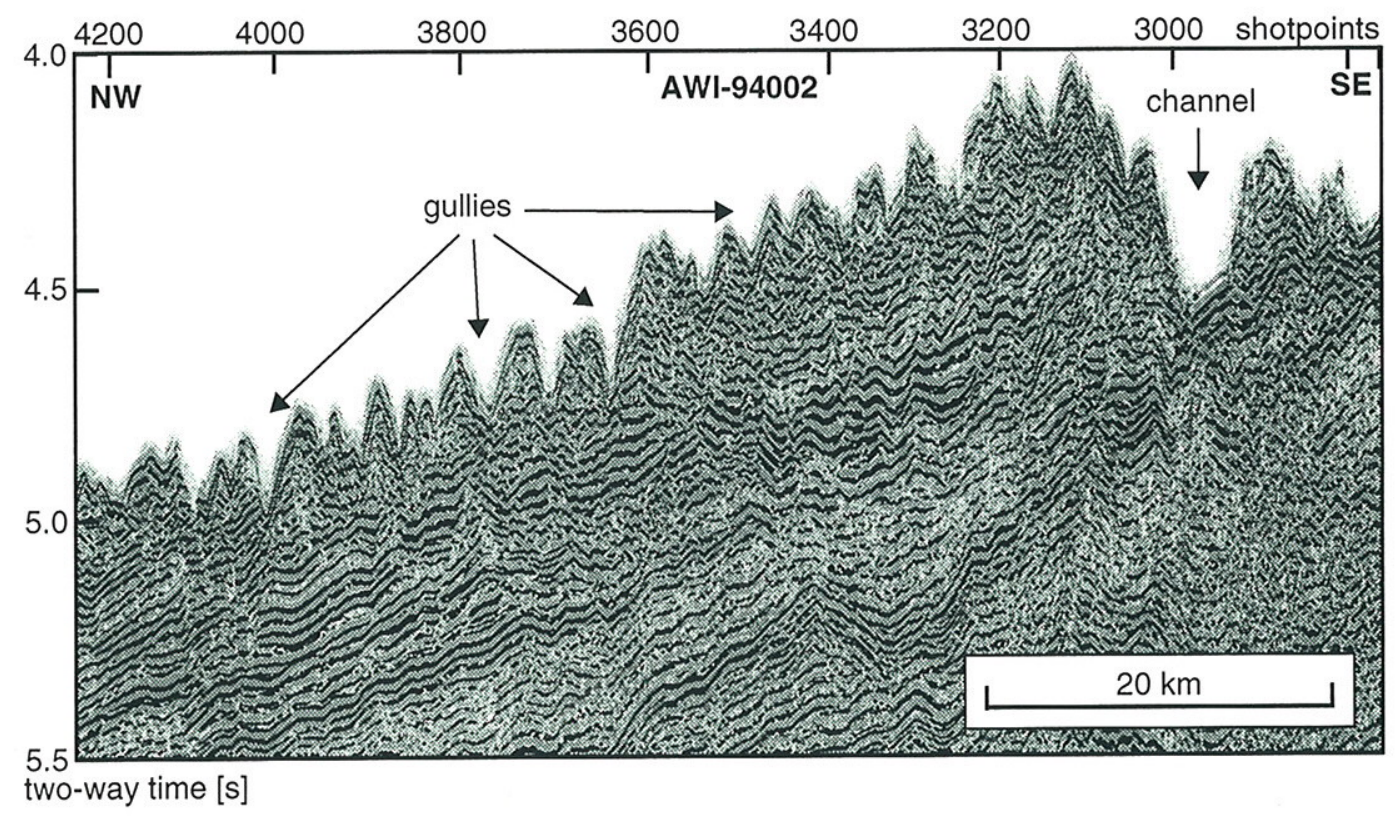

Fig. 4. Close up of a mound on the upper rise of AWI-94002. The top is dissected by gullies and small channels. A larger channel marks the southern end of the mound. Comparison with the data of Rebesco et al. [1996] shows that this line runs along the dissected southwest slope of their mound 8 .

wedge is divided into two parts by changing from steeper reflections in the lower part to more gently dipping ones in the upper part.

\subsection{Line AWI-94042, Eastern Amundsen Sea}

The westernmost complete transect, line AWI-94042 (Figure 8), shows a continental slope which (at 3 to 4 degrees) is slightly steeper, and thus narrower than on the two profiles discussed previously. The water depth at the shelf edge is approximately $540 \mathrm{~m}$. Two phases of outer shelf develøpment are evident in this location: a phase of mainly progradation (Unit 2), followed by a phase of combined progradation and aggradation (Unit 3). The aggradational component of the latter accounts for a quite thick (400ms) sediment cover over the continental shelf. Combined progradation of the two units amounts to at least $24 \mathrm{~km}$. Line AWI-94042 has a very short extension on the continental shelf. This makes it impossible to identify clearly a lower Unit 1 and the lower boundary of Unit 2 on this section.

Again, a pronounced erosional surface, with characteristic wavy-hummocky morphology, defines the base of a prograding wedge on the continental slope (not shown here). This wedge is up to $1.8 \mathrm{~s}$ thick, but relatively narrow. Coincident with the prominent downlap of internal strata onto its base, the wedge quickly thins to a mere $100 \mathrm{~ms}$ at the foot of the slope. In the lower part of the wedge, a strongly reflecting horizon is recognized, which becomes less distinct towards the upper slope, but appears to lie approximately along the continuation of the boundary separating progradational (Unit 2) and progradational/aggradational sequences (Unit 3) on the outer shelf. Below the wedge, at least 2.0 s of older sediments are evident, most of which are not recognized on the other profiles. Because this rifted margin has been a passive margin for much longer (since $\sim 85 \mathrm{Ma}$ ) than the Bellingshausen Sea margin farther east, which became passive at $50-60 \mathrm{Ma}$, it is likely that the continental slope here accommodates the oldest sedimentary succession along the investigated margin.

The remaining transect farther west in the central Amundsen Sea (lines AWI-94050 and 94054) did not extend to the outer shelf. The sediment layer of the continental rise is disturbed by basement highs and small seamounts [Gohl et. al., in press b]. Therefore these lines cannot be compared with the lines farther east.

\section{DISCUSSION}

On all the investigated parts of the West Antarctic margin the same variations of outer shelf geometry are observed: (1) a lower unit of parallel, horizontal and/or gently dipping sequences, (2) a middle unit of strongly 


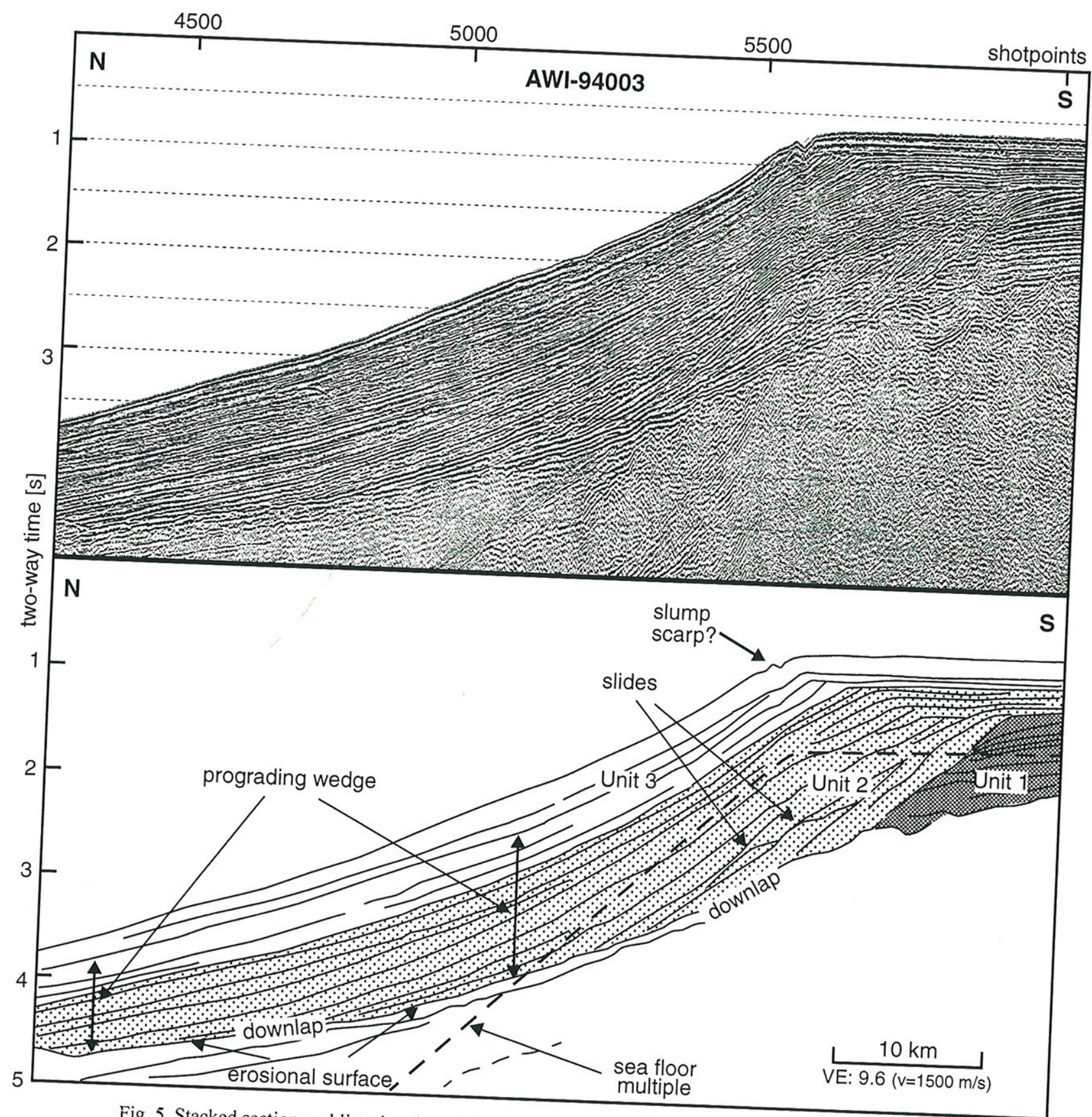

Fig. 5. Stacked section and line drawing of the outer shelf and continental slope of line AWI-94003. addition, an erosional surface is seen on thilar characteristics to the units identified in Figure 3 . In

prograding sequences, and (3) an upper unit exhibiting both progradation and aggradation. The lower unit (Unit 1) closely resembles the "Type IIA" sequences, as defined by Cooper et al. [1991] at various locations along the Antarctic continental margin. As mentioned, these sequences are thought to represent conditions prior to the major glacial advances.
The overlying sediments all show significant seaward migration of the paleo-shelf edge, indicating a major change in depositional style. By analogy with observations from similar glaciated margins [e.g. Larter and Barker, 1989, 1991a; Boulton, 1990; Bartek et al., 1991; Cooper et al., 1991; Kuvaas and Kristoffersen, 1991; Vanneste et al., 1995] Units 2 and 3 are interpreted 


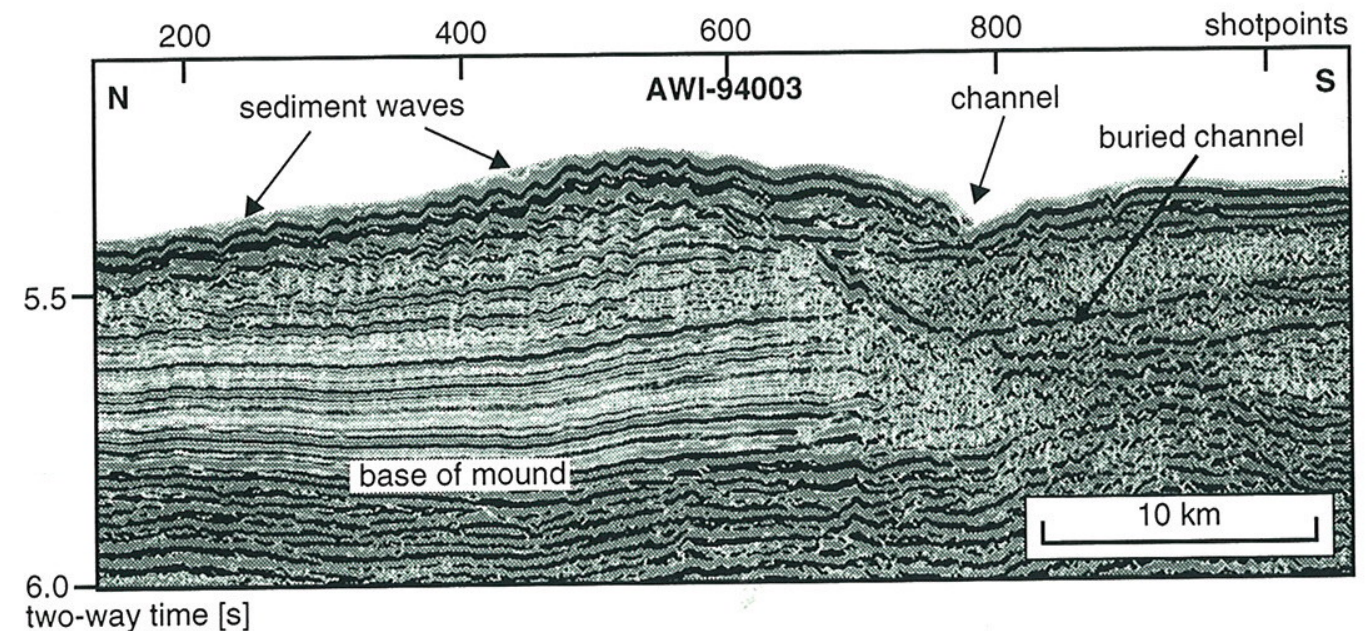

Fig. 6. Seismic section of a mound on the lower continental rise of AWI-94003. Note the sediment waves in the upper part of the mound. A channel (underlain by a buried channel) marks the southern end of the mound.

as mainly glacial in origin. However, a glacial origin cannot confidently be established for individual sequences without additional drilling results. On the other hand, the identification at the southern end of line AWI-94002, where the line runs almost parallel to the shelf edge (up to shot point 1500), of a broad erosional trough (Figure $2 \mathrm{a}$ ), in shelf sediments correlative to the two upper progradational units, provides support for this hypothesis.

Age constraints for the onset of large-scale glaciation of the shelf are limited at present. Results from DSDP Leg 35 on the Bellingshausen continental rise suggest that, although local alpine glaciation on the continent may have started as early as Eocene [e.g. Birkenmajer, 1991], major West Antarctic glaciation probably began in late Miocene time, indicated by an increase in ice rafted material found in DSDP sites of Leg 35 [Hollister et al., 1976]. Farther east along the Antarctic Peninsula margin, Larter and Barker [1991a] correlate prograding sequences on the shelf with sediments on the continental rise that overlie young ocean floor. They estimated the age of this ocean floor by interpretation of marine magnetic anomalies as $5.6 \mathrm{Ma}$ (6.5 Ma under the revised geomagnetic polarity timescale of Cande and Kent [1995]).

The two upper units identified on the outer shelf would thus have been deposited during multiple glacial advances on the shelf, which caused deposition in an overall progradational style. Erosion was predominant on the inner shelf, while aggradation of shelf strata was restricted to the outer shelf. Although Unit 2 shows little aggradation this does not mean that there was no aggradation, but during times when grounded ice advanced to the shelf edge the top may have been eroded.
Even though it has been shown on the Antarctic Peninsula shelf farther east that amounts of progradation and aggradation can vary greatly laterally within a given glacial sequence [Larter and Cunningham, 1993; Bart and Anderson, 1995], we believe the widespread transition from progradational to both prograding and aggrading sequences is significant, reflecting a broadly similar long-term glacial development along the entire margin. Other authors reported similar geometries from the Pacific[Barker, 1995; Bart and Anderson, 1995] and the Weddell Sea [Sloan et al., 1995] margins of the Antarctic Peninsula, and from the Ross Sea [ Bartek et al., 1991; Barker, 1995]. According to these authors the change from aggradation to progradation occurred around the Miocene/Pliocene boundary and the change from mainly progradation to aggradation in the late Pliocene. The cause of these changes is still under debate. Barker [1995] suggested that progradation is increased during a period of faster-flowing ice during the warmer climate of the early Pliocene. Bart and Anderson [1995] proposed a model which includes short-duration ice sheets producing more aggradational sequences in late Miocene and after late Pliocene and long-duration ice sheets during early Pliocene resulting in mainly progradational sequences.

These models do not imply, however, that the advancing ice sheets reached the outer shelf at the same time everywhere along the entire margin, or were of equal magnitude. Considering the great variations of shelf width and the position of the shelf ice of today, such an evolution is not likely. For example, the grounded ice has to advance over a greater distance in the central Bellingshausen Sea than at the Antarctic Peninsula, to 


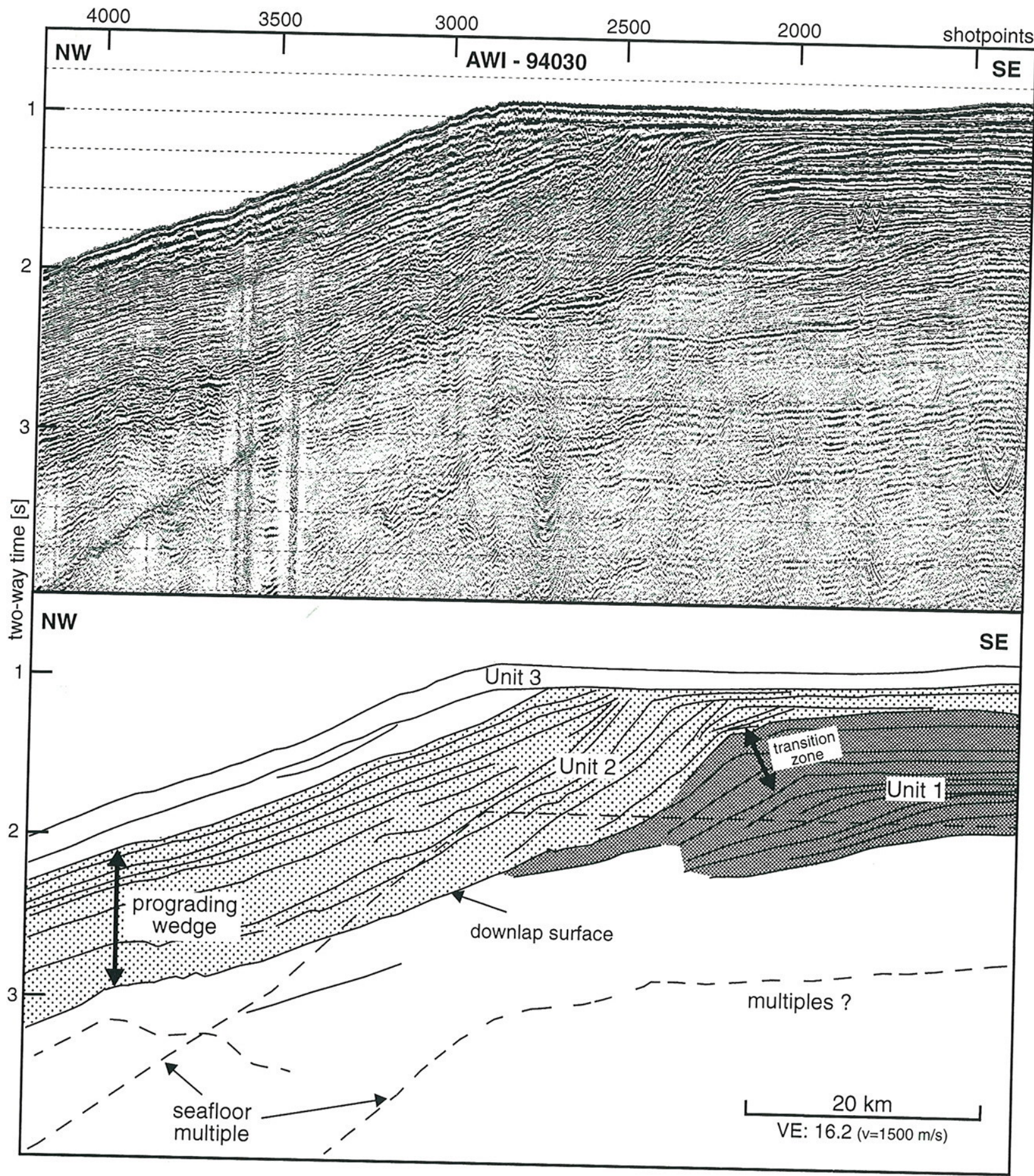

Fig. 7. Stacked section and interpretive line drawing of the outer shelf and slope of line AWI-94030. Units 1, 2 and 3 resemble those of Figures 3 and 4. The base of Unit 1 is hidden by multiple reflections. The transition between Unit 1 and Unit 2 appears as a broader zone than in the other lines. 


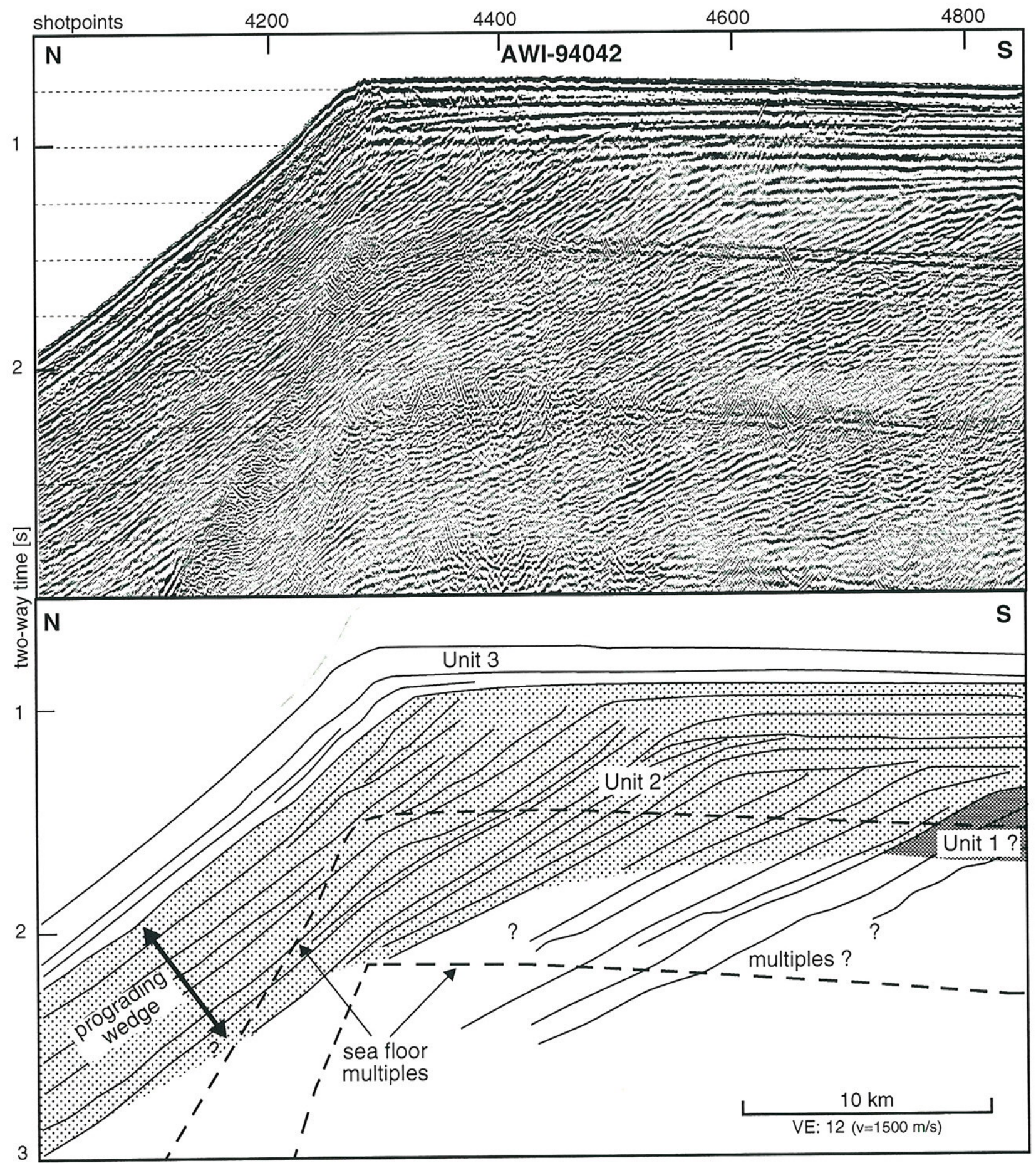

Fig. 8. Part of line AWI-94042 and interpretive line drawing showing the outer shelf and the upper part of the continental slope. In contrast to figures 3, 4 and 5, there is no clear indication of Unit 1 in this section: the lower part of the outer shelf is obscured by multiple sea floor reflections, so that the base of Unit 2 is not seen. 
reach the shelf edge. Also it is unlikely that the rate of ice advance was constant along the margin. Investigations along the Antarctic Peninsula show that ice streams cause lateral variations in sediment deposition [Larter and Cunningham, 1993].

On the continental slope an erosional surface is observed, defining the base of a wedge of prograding and downlapping slope foresets. A similar unconformity is found in other Antarctic regions which Cooper et al. [1993] interpreted as the boundary between nonglacial and glacial deposition. Our interpretation is that here also the erosional surface approximates to the transition from Type IIA to characteristically prograding sequences Type IA on the outer shelf (our Unit 1 to Unit 2). This implies that it is related to the onset of the major advance of the grounded ice sheet. However, caution is needed since there is no clear correlation of this surface from the slope to the shelf.

Indications of slumps and slides on the continental slope and large sediment mounds on the continental rise show that sediment reworking by gravity and currents plays an important role in the sedimentation history. Rebesco et al. [1994, 1996] discovered similar mounds along the Pacific margin of the Antarctic Peninsula. According to them these features are hemipelagic drifts, arising from the interaction of sediments brought to the continental rise by turbidity currents and a southwesterly bottom current.

In general, two separate phases in sedimentation history are discerned, a later phase involving pronounced outer shelf progradation and thus related to the glacial development of the margin, and an earlier phase which was not directly affected by grounded ice. The temporal relationship between progradation on the upper slope and accumulation on the continental rise is poorly defined.

Striking similarities are found in the seismic structure of the outer shelf and continental slope along the whole margin, although the spacing between lines and the lack of strike lines make it difficult to correlate reflections from line to line. Changes in the sedimentary pattern between the lines are evident, but major differences are not seen. The profiles show differences in slope, depth of shelf and amount of progradation. These could be caused by differences in glacial drainage patterns, the nature of the source material being eroded, the transport path and other parameters. They could also reflect variations in the tectonic history of the western Bellingshausen Sea and the Antarctic Peninsula [Tucholke and Houtz, 1976].

\section{CONCLUSIONS}

A regionally-spaced reflection seismic data set has been acquired from the largely unexplored Bellingshausen and Amundsen Seas along the West Antarctic margin. Though limited in coverage, these data show the largescale stratigraphic architecture of the continental shelf, slope and rise.

Everywhere on the outer shelf the same transitions are noted, from mainly aggrading to purely prograding, and subsequently into both prograding and aggrading geometries. The lower sequences (Unit 1) are thought to represent conditions before the onset of major advance of the grounded ice, whereas the overlying sequences probably record several extended periods of ice sheet grounding on the shelf since the late Miocene.

A prominent erosional surface defines the base of a prograding wedge occupying the continental slope along the margin. It is tentatively correlated with the upward transition from preglacial sedimentation to deposits of a waxing and waning grounded ice sheet on the outer shelf. Sedimentation on the continental rise is controlled by confined turbidity currents derived from the continental margin. They have resulted in the construction of large sediment drifts as a result of interaction with bottom cur-
rents.

We hope the results of this reconnaissance survey will provide a new impulse to the scientific community to gather more seismic and other data, needed for a more detailed assessment of the long-term history of glaciation of the West Antarctic margin.

Acknowledgments. We are grateful to the captain and crew of the RV Polarstern for their support during cruise ANT-XI/3, particularly in times of heavy weather and severe ice conditions. Laszlo Oszko, thank Notker Fechner, Christian Hübscher, Estella Weigelt, Manfred Böchartmut Martens, Eric Maes, Astrid Lambrecht, assistance during Vanneste during operation of the seismic equipment. Kris assistant of the ANT-XI/3 survey as a research the framework Belgian National Fund for Scientific Research in (Phase III) supported Scientific, Technicaled by the Belgian Federal Office for Rob Larter and Peter Barker Affairs. We thank Ben Sloan, comments and Peter Barker for their critical reviews and Wegener-Instituve greatly improved the paper. This is AlfredWegener-Institute contribution No. 1037. 


\section{REFERENCES}

Anderson, J. B., and L. R. Bartek, Cenozoic glacial history of the Ross Sea revealed by intermediate resolution seismic reflection data combined with drill site information, in The Antarctic Paleoenvironment: A Perspective on Global Change,Antarct. Res. Ser. 56, edited by J. P. Kennett and D. A. Warnke, pp. 231-263, AGU, Washington D. C., 1992.

Anderson, J. B., L. R. Bartek, and M. A. Thomas, Seismic and sedimentological record of glacial events on the Antarctic Peninsula shelf, in Geological Evolution of Antarctica, edited by M. R. A. Thomson, J. A. Crame, and J. W. Thomson, pp. 687-691, Cambridge University Press, Cambridge, 1991.

Barker, P. F., The proximal marine sediment record of Antarctic climate since the late Miocene, in Geology and Seismic Stratigraphy of the Antarctic Margin, Antarct. Res. Ser., 68, edited by A. K. Cooper, P. F. Barker and G. Brancolini, pp. 25-57, AGU, Washington, D. C., 1995.

Bart, P. J., and J. B. Anderson, Seismic record of glacial events affecting the Pacific margin of the nortwestern Antarctic Peninsula, in Geology and Seismic Stratigraphy of the Antarctic Margin, Antarct. Res. Ser., 68, edited by A. K. Cooper, P. F. Barker and G. Brancolini, pp. 74-95, AGU, Washington, D. C., 1995.

Bartek, L. R., P. R. Vail, J. B. Anderson, P. A. Emmet and S. Wu, Effect of Cenozoic ice sheet fluctuations in Antarctica on the stratigraphic signature of the Neogene, J. Geophys. Res., 96, 6753-6778, 1991.

Birkenmajer, K., Tertiary glaciation in the South Shetland Islands, West Antarctica, in Geological Evolution of Antarctica, edited by M. R. A. Thomson, J. A. Crame and J. W., Thomson, Cambridge University Press, Cambridge, pp. 629-632, 1991.

Boulton, G.S., Sedimentary and sea level changes during glacial cycles and their control on glacimarine facies architecture, in Glacimarine Environments: Processes and Sediments. Special Publication 53, edited by J. A. Dowdeswell and J. D. Scourse, The Geological Society, London, pp. 15-52, 1990.

Cande, S. C. and D. V. Kent, Revised calibration of geomagnetic polarity timescale for the Late Cretaceous and Cenozoic, J. Geophys. Res., 100, 6093-6095, 1995.

Cooper, A. K., P. J. Barrett, K. Hinz, V. Traube, G. Leitchenkov, and H. M. J. Stagg, Cenozoic prograding sequences of the Antarctic continental margin: a record of glacio-eustatic and tectonic events, Marine Geology, 102, 175-213, 1991.

Cooper, A. K., S. Eittreim, U. T. Brink, I. Zayatz, Cenozoic glacial sequences of the Antarctic continental margin as recorders of Antarctic ice sheet fluctuations, in The Antarctic paleoenvironment: a perspective on global change, part 2, Antarct. Res. Ser., 60, edited by J. P. Kennett and D. A. Warnke, pp. 75-89, AGU, Washington, D. C., 1993.

Cunningham, A. P., R. D. Larter, and P. F. Barker, Glacially prograded sequences on the Bellingshausen Sea continental margin near $90^{\circ} \mathrm{W}$, Terra Antartica, 1, 267-268, 1994.
Drewry, D. J., Antarctica: Glaciological and Geolophysical Folio, Scott Polar Res. Inst., Cambridge England, 9 sheets, 1983.

Ehrmann, W. U., and A. Mackensen, Sedimentological evidence for the formation of an East Anarctic ice sheet in Eocene/Oligocene time, Palaeogeography, Palaeoclimatology, Palaeoecology, 93, 85-112, 1992.

Gohl, K., F. O. Nitsche and H. Miller, Seismic and gravity data reveal tertiary intra-plate subduction in the Bellingshausen Sea, South-East Pacific, Geology, in press a.

Gohl, K., F. O. Nitsche, K. Vanneste, H. Miller, N. Fechner, L. Oszko, C. Hübscher, E. Weigelt and A. Lambrecht, Tectonic and sedimentary architecture of the Bellingshausen and Amundsen Sea basins, SE Pacific, by seismic profiling, Terra Antartica, in press b.

Hollister, C. D., C. Craddock et al., Initial Reports of the Deep Sea Drilling Project, 35, 929 pp., US Government Printing Office, Washington, DC, 1976.

Kuvaas, B., and Y. Kristoffersen, The Crary Fan: A troughmouth fan on the Weddell Sea continental margin, Antarctica. Marine Geology, 97, 345-362, 1991.

Kimura, K., Geological and geophysical survey in the Bellingshausen Basin, off Antarctica, Antarctic Record, 75, 12-24, 1982.

Larter, R. D., and P. F. Barker, Seismic stratigraphy of the Antarctic Peninsula Pacific margins: A record of PliocenePleistocene ice volume and paleoclimate, Geology, 17, 731734, 1989.

Larter, R. D., and P. F. Barker, Neogene interaction of tectonic and glacial processes at the Pacific margin of the Antarctic Peninsula, Spec. Publs. int. Ass. Sediment., 12, edited by D. I. M. Macdonald, pp. 165-186, Blackwell, Oxford, 1991a.

Larter, R. D., and P. F. Barker, Effects of ridge crest-trench interaction on Antarctic-Phoenix spreading: forces on a young subducting plate, J. Geophys. Res., 96, 19583-19607, 1991 b.

Larter, R. D., and A. P. Cunningham, The depositional pattern and distribution of glacial-interglacial sequences on the Antarctic Peninsula Pacific margin, Marine Geology, 109, 203-219, 1993.

Lawver, L. A., L. M. Gahagan, and M.F. Coffin, The development of paleoseaways around Antarctica, in The Antarctic Paleoenvironment: A Perspective on Global Change, I, Antarct. Res. Ser. 56, edited by J. P. Kennett and D. A. Warnke, pp. 7-30, AGU, Washington, D. C., 1992.

McAdoo, D., and K. Marks, Gravity fields of Southern Oceans from Geosat Data, J. Geophys. Res., 97, 3247-3260, 1992.

McGinnis, J. P., and D. E. Hayes, Sediment drift formation along the Antarctic Peninsula, Terra Antartica, 1, 275-276, 1994.

Rebesco, M., R. D. Larter, P. F. Barker, A. Camerlenghi and L. E. Vanneste, The history of sedimentation on the continental rise west of the Antarctic Peninsula, Terra Antartica, 1, 277-279, 1994.

Rebesco, M., R. D. Larter, A. Camerlenghi and P. Barker, Giant sediment drifts on the continental rise west of the Antarctic Peninsula, Geo-Marine Letters, 16, 65-75, 1996. 
Sloan, B. J., L. A. Lawver and J. B. Anderson, Seismic stratigraphy of the Larsen basin, eastern Antarctic Peninsula, in Geology and Seismic Stratigraphy of the Antarctic Margin, Antarct. Res. Ser., 68, edited by A. K. Cooper, P. F. Barker 1995. Brancolini, pp. 59-74, AGU, Washington, D. C.,

Tucholke, B. E., and R. E. Houtz, Sedimentary framework of the Bellingshausen Basin from seismic profiler data, in Initial Reports of the Deep Sea Drilling Project, 35, 197-227, Washington, D.C., 1976.

Vanneste, K., G. Uenzelmann-Neben and H. Miller, Seismic evidence for the long-term history of glaciation on the central East Greenland shelf south of Scoresby Sund. GeoMarine Letters, 15, 63-70, 1995.
Karsten Gohl, Macquarie University, School of Earth Sciences, Sydney, NSW 2109, Australia

Heinz Miller, Alfred Wegener Institute for Polar and Marine Research, Columbusstr., D-27568 Bremerhaven, Germany.

Marine Research, Alfred Wegener Institute for Polar and Germany.

Kris Vanneste, Royal Observatory of Belgium, Ringlaan 3, B-1180 Brussels, Belgium

(Received July 6, 1995; accepted March 17, 1997) 